\title{
The Research on Low-Carbon Level of Shipping Industry Based on Fuzzy Algorithm
}

\author{
Li Yan \\ Transportation Management School \\ Dalian Maritime University \\ Dalian, China \\ lilyyanfire@163.com
}

\author{
Liu Ye \\ Transportation Management School \\ Dalian Maritime University \\ Dalian, China
}

\author{
Huang Qingbo* \\ Transportation Management School \\ Dalian Maritime University \\ Dalian, China \\ hqb4950@126.com \\ *Corresponding author
}

\begin{abstract}
The low-carbon sea transportation is characterized by "marine shipping and emission reduction of load and unload on the ports of call". It suits the historical trend of development, and is the objective requirement of the sustainable development of China's shipping industry. The level of low-carbon sea transportation involves various factors such as technology and management, thus it requires systematic analysis and comprehensive assessment. Based on the analysis of the status quo of China's shipping industry, this article uses comprehensive fuzzy appraisal, establishes fuzzy matrix, measures the development level of China's maritime industry and proposes countermeasures and suggestions including the aspects of adjusting industry and energy structure, enhancing technology research and development, improving transport ships and increasing investment.
\end{abstract}

Keywords-low-carbon level; fuzzy algorithm; shipping industry

\section{INTRODUCTION}

With the global warming increased, the society pays more and more attention to the development of low-carbon economic. Along with the continuous growth of the global international trade goods, international cargo operation scale and the increase in energy consumption of shipping, the problem of the reduction of low carbon in shipping industry is becoming a focus for the international maritime organization (IMO) and the developed countries. According to a report of IMO, the international shipping industry $\mathrm{CO}_{2}$ emissions accounts for about $3 \%$ of global $\mathrm{CO}_{2}$ emissions. If not controlled, the carbon footprint of international shipping industry will grow by five times in 2050, accounting for $18 \%$ of total global $\mathrm{CO}_{2}$ emissions. If $\mathrm{CO}_{2}$ emissions in shipping industry can't be reduced effectively, the situation will be negative.

In 2014, the state council on several opinions for promoting the healthy development of shipping industry saying: our government has made it clear that making the shipping industry development a national strategy. The sustained and healthy development of the marine service trade is becoming an im-

The paper is subsidized by Liaoning province social science fund project (L14AJY001, L15BJL015) and Basic scientific research fund project of central university (3132016037). portant issue. Among them, reducing $\mathrm{CO}_{2}$ emissions in the shipping industry is the key to promote the sustainable development of shipping industry in our country.

In this paper, fuzzy algorithm has been used to study the level of low carbon through the establishment of shipping industry evaluation index system. Then this paper uses fuzzy comprehensive evaluation to assess the indicators. According to the results of the analysis, this paper tries to optimize the path for the development of low-carbon development of China's shipping industry.

\section{REVIEW OF LITERATURE}

At present, scholars at home and abroad mainly focus in the field of low-carbon economy. The research of marine low carbon is less. Li jing (2011)[1] analyzed the carbon tax's influence on China's shipping industry through the construction of CGE model. The results show that the impact of carbon tax has two sides. On the one hand, it can effectively reduce the shipping industry $\mathrm{CO} 2$ emission, and on the other hand, it also can cause the loss of shipping traffic volume and the rise of freight rate. Zhang shuang, Zhang Shuohui, Li Yiliang (2008) [2] thought if ship speed reduces $4 \%$, the emission of greenhouse gases will reduce $13 \%$.However the fuzzy algorithm is less applied to the articles for low carbon economy. Wang Jiarui (2014)[3] structured the hierarchical index evaluation system and made empirical analysis for the low carbon economy in our country. He established the index system of three layers and 20 indicators were formed. The results of empirical analysis show that the effect of resource factors to the development of low carbon economy in our country is the most important. The effect of environmental factor and economic factor to the low-carbon economy level is similar. Liu Xiaomei (2013)[4] used the fuzzy analytic hierarchy process (FAHP) to evaluate the low carbon economy development level quantitatively. He pointed out the existing problems in the development of low carbon economy at present, such as the level of social development, science and technology and the 
public awareness of low carbon has huge gap among developed countries and developing countries. The related statistical data is seriously short and due to the lack of effective measurement tools, the evaluation system of carbon emissions and dimension cannot be unified and so on. Wang Hong, Liu $\mathrm{Na}$, Song Yajing (2013)[5] applied the fuzzy comprehensive evaluation model to the study of urban low-carbon economy evaluation. They established a set of evaluation index system which can be used in the low carbon economy, based on the basic principles of scientific and operability. The preliminary evaluation had made in low carbon economy development level of Beijing. Bi Peng, Zhang Liting (2013)[6] applied the fuzzy comprehensive evaluation method to study the lowcarbon economic development level of Hei Longjiang province.

In terms of study abroad, there are no articles about the fuzzy algorithm for marine low carbon. Most have focused on the carbon emissions of shipping industry. Erik Haites(2009)[7] analyzed the development of shipping industry planning problem based on the global carbon emissions trading. Williams(2008)[8] put forward measures to effectively reduce and absorb the processing scheme, mainly based on the angle of marine shipping merchant fleet emissions problem. Windson(2008)[9] put forward a number of indicators affecting the development of shipping, the sustainable development index system for shipping is formed. And the mathematical model is used to forecast the trend for future route of green shipping development. Thomas (2007)[10] studied the relationship between containers ship speed and carbon emissions. He found that within a certain range, to reduce containers ship speed could effectively reduce $\mathrm{CO} 2$ emissions, but the slowdown would extend sailing time. This not only increased the cost of inventory, but also easy to high risk during the transit.

Therefore, with the integration of the existing research, scholars at home and abroad focus on the low carbon industry and apply fuzzy algorithm to the field of low carbon economy. However, the fuzzy algorithm is less applied to marine low carbon level. This paper will establish an evaluation index system for marine low carbon, build a fuzzy comprehensive evaluation model, make empirical analysis of China's shipping industry low carbon, and finally put forward the strategy for the development of marine low carbon.

\section{The CuRREnt Situation of LOW-Carbon Development IN CHINA'S SHIPPING INDUSTRY}

Due to the ship facilities and technology, the fuel quantity of Chinese shipping industry is large, which leads to a large amount of carbon dioxide emissions. At present, the development of China's low-carbon shipping industry is still in its infancy, and there is still a great gap between china and the developed countries. In order to reflect the current situation of the development of China's low-carbon shipping industry, this article chooses the amount of $\mathrm{CO}_{2}$ emissions from international maritime transport of fuel to measure the carbon emissions situation of China's shipping industry.

The $\mathrm{CO}_{2}$ emissions of international maritime fuel increased from 27.34 million tons in 2003 to 54.73 million tons in 2012, the amount has nearly tripled. Especially in 2010, it reached a peak of 66.21 million tons. In 2005, $\mathrm{CO}_{2}$ emissions reduced 3.82 million tons less than 2004. One important reason was that the "Kyoto Protocol" came into force in 2005. As one of the commitment countries, Chinese government actively fulfilled their obligations and took a series of effective measures to reduce emissions of $\mathrm{CO}_{2}$. In 2008, the $\mathrm{CO}_{2}$ emissions of international maritime fuel reduced again, about 4.23 million tons compared with 2007 . This was greatly affected by the 2008 financial crisis in which the shipping industry economy was bad and the amount of shipbuilding and port container were reduced, thus the decrement of $\mathrm{CO}_{2}$ emissions was obvious.

China's $\mathrm{CO}_{2}$ emissions of shipping industry account for a large proportion and it continued to increase in volatility. It rose from $5.6 \%$ in 2003 to $9.1 \%$ in 2012 , which reached the maximum of $10.1 \%$ in 2010 . WTO data shows that China's seaborne trade services market share roughly accounts for $2 \%$ of the world. It shows that under the circumstance of low occupancy, China's $\mathrm{CO}_{2}$ emissions of shipping industry are relatively large. Therefore, the problem of carbon emissions of shipping industry is urgent to be resolved.

\section{The Level of Development of China's Shipping INDUSTRY CARBON MEASUREMENT UNDER FUZZY COMPREHENSIVE EVALUATION}

\section{A. Evaluation Index}

Achieve the goal of low-carbon development and establish an evaluation factor set by the Analytic Hierarchy Process, $U$ $=\{\mathrm{U} 1, \mathrm{U} 2, \mathrm{U3}, \cdots, \mathrm{Un}\}, \mathrm{U}$ is a finite set of evaluation index. This article selected 17 indicators from industry factors, energy factors, technical factors, transport factors and environmental factors five angles to build evaluation system. (TABLE 1)

TABLE I. EVALUATION LIST OF CARBON SHIPPING

\begin{tabular}{c|l}
\hline $\begin{array}{c}\text { Industry } \\
\text { factor }\end{array}$ & $\begin{array}{l}\text { (1)Maritime trade as a share of GDP } \\
\text { (2)Maritime trade carbon emissions of ten thousand yuan } \\
\text { (3)Maritime Environmental Protection Industry as a share of } \\
\text { maritime trade }\end{array}$ \\
\hline $\begin{array}{c}\text { Energy } \\
\text { factor }\end{array}$ & $\begin{array}{l}\text { (4)Marine fuel oil as a share of the total energy } \\
\text { (5)Clean energy(clean coal) as a share of the total energy } \\
\text { (6)Renewable energy sources as a share of the total energy }\end{array}$ \\
\hline $\begin{array}{c}\text { Technolo } \\
\text {-gy factor }\end{array}$ & $\begin{array}{l}\text { (7)Expense of technology as a share of maritime trade } \\
\text { (9)Unit seaborne trade in energy consumption } \\
\text { (10)High-efficient utilizing technology of Clean Energy }\end{array}$ \\
$\begin{array}{l}\text { (11)Intelligent Power Technology } \\
\text { (12)Maritime Waste technology }\end{array}$ \\
\hline fansport & $\begin{array}{l}\text { (13)Carbon emissions of traveling in thousands of miles } \\
\text { (14)The number of old vessels ship as a share of the total }\end{array}$ \\
\hline $\begin{array}{c}\text { Environ- } \\
\text { ment } \\
\text { factor }\end{array}$ & $\begin{array}{l}\text { (15)Funding for environmental governance } \\
\text { (16)Funding for water pollution treatment } \\
\text { (17)Degree of treatment of other pollutants }\end{array}$ \\
\hline
\end{tabular}

\section{B. Comments Set}

Comments set are the way to evaluate the level of lowcarbon development of the shipping industry. According to the development of low-carbon shipping industry, this article set up five evaluation levels, $\mathrm{V}=\{\mathrm{V} 1, \mathrm{~V} 2, \mathrm{~V} 3, \mathrm{~V} 4, \mathrm{~V} 5\}=\{$ very high, higher, average, lower, and very low . Rank domain is determined to make fuzzy comprehensive evaluation with a 
fuzzy evaluation vector and represent the degree of membership of the objectives which is evaluated through the fuzzy vector.

\section{Judgment Matrix}

To determine the weights, this article took the method of experts scoring, which invited 15 experts to evaluate. Then, this article used yaahp software of AHP to process and to obtain the following results (TABLE 2).

TABLE II. LOW-CARBON SHIPPING EST IMATE INDEX AND THE WEIGHT

\begin{tabular}{|c|c|c|c|c|c|c|c|c|}
\hline \multirow{2}{*}{ Factor } & \multirow{2}{*}{$\begin{array}{l}\text { Wei- } \\
\text { ght }\end{array}$} & \multirow{2}{*}{$\begin{array}{c}\text { Divi- } \\
\text { sor }\end{array}$} & \multirow{2}{*}{$\begin{array}{c}\text { Wei- } \\
\text { ght }\end{array}$} & \multicolumn{5}{|c|}{ Assessment Level* } \\
\hline & & & & 1 & 2 & 3 & 4 & 5 \\
\hline \multirow{3}{*}{$\begin{array}{l}\text { Industry } \\
\text { Factor }\end{array}$} & \multirow{3}{*}{0.2244} & (1) & 0.1494 & 0 & 0.2 & 0.4 & 0.8 & 0 \\
\hline & & (2) & 0.4742 & 0.3 & 0.5 & 0.4 & 0.2 & 0.1 \\
\hline & & (3) & 0.3764 & 0.1 & 0 & 0.1 & 0.9 & 0.3 \\
\hline \multirow{3}{*}{$\begin{array}{l}\text { Energy } \\
\text { Factor }\end{array}$} & \multirow{3}{*}{0.1568} & (4) & 0.2000 & 0.1 & 0.6 & 0.3 & 0.4 & 0 \\
\hline & & (5) & 0.4000 & 0 & 0 & 1.0 & 0.3 & 0.1 \\
\hline & & (6) & 0.4000 & 0.5 & 0.1 & 0.2 & 0.6 & 0.5 \\
\hline \multirow{6}{*}{$\begin{array}{l}\text { Techno- } \\
\text { lo-gy } \\
\text { Factor }\end{array}$} & \multirow{6}{*}{0.3688} & (7) & 0.1092 & 0.1 & 0 & 0.2 & 0.5 & 0.5 \\
\hline & & (8) & 0.0708 & 0.2 & 0.5 & 0.1 & 0.2 & 0.4 \\
\hline & & (9) & 0.2082 & 0 & 0 & 0.5 & 0.7 & 0.1 \\
\hline & & (10) & 0.2227 & 0 & 0.3 & 0.4 & 0.7 & 0 \\
\hline & & (11) & 0.1946 & 0 & 0 & 0.4 & 0.8 & 0.2 \\
\hline & & (12) & 0.1946 & 0 & 0 & 0.3 & 0.5 & 0.6 \\
\hline \multirow{2}{*}{$\begin{array}{l}\text { Transpo- } \\
\text { rt Factor }\end{array}$} & \multirow{2}{*}{0.1568} & (13) & 0.2000 & 0.2 & 0.6 & 0.2 & 0.4 & 0 \\
\hline & & (14) & 0.8000 & 0.1 & 0.5 & 0.6 & 0.2 & 0 \\
\hline \multirow{3}{*}{$\begin{array}{l}\text { Environ- } \\
\text { ment } \\
\text { Factor }\end{array}$} & \multirow{3}{*}{0.0932} & (15) & 0.3275 & 0 & 0.1 & 0.2 & 0.8 & 0.3 \\
\hline & & (16) & 0.2599 & 0 & 0.1 & 0.4 & 0.7 & 0 \\
\hline & & (17) & 0.4126 & 0 & 0 & 0.4 & 0.5 & 0.5 \\
\hline
\end{tabular}

We compared the importance of any two indexes throw yaahp software, after a consistency check, obtain judgment matrix:

$$
\begin{aligned}
\mathrm{W} & =\left\{\mathrm{W}_{1}, \mathrm{~W} 2, \mathrm{~W} 3, \mathrm{~W} 4, \mathrm{~W} 5\right\}^{\mathrm{T}} \\
& =\{0.2244,0.1568,0.3688,0.1568,0.0932\}^{\mathrm{T}}
\end{aligned}
$$

\section{Fuzzy Matrix}

After determining the weight, the fuzzy matrix needs to be determined, according to the calculations of judgment matrix and assessment level.

Fuzzy Matrix R=

$$
\left(\begin{array}{llllll}
0.1799 & 0.2670 & 0.2871 & 0.5531 & 0.1603 \\
0.2200 & 0.1600 & 0.5400 & 0.4400 & 0.2400 \\
0.0251 & 0.1022 & 0.3583 & 0.6234 & 0.2594 \\
0.1200 & 0.5200 & 0.5200 & 0.2400 & 0.0000 \\
0.0000 & 0.0587 & 0.3345 & 0.6502 & 0.3045
\end{array}\right)
$$

E. Comprehensive evaluation results

$\mathrm{B}=\mathrm{W} \times \mathrm{R}=\left(\begin{array}{l}0.22440 .15680 .36880 .15680 .0932\end{array}\right) \times$

$$
\begin{gathered}
\left(\begin{array}{llllll}
0.1799 & 0.2670 & 0.2871 & 0.5531 & 0.1603 \\
0.2200 & 0.1600 & 0.5400 & 0.4400 & 0.2400 \\
0.0251 & 0.1022 & 0.3583 & 0.6234 & 0.2594 \\
0.1200 & 0.5200 & 0.5200 & 0.2400 & 0.0000 \\
0.0000 & 0.0587 & 0.3345 & 0.6502 & 0.3045
\end{array}\right) \\
=\left(\begin{array}{llllll}
0.1029 & 0.2097 & 0.3939 & 0.5212 & 0.1976
\end{array}\right)
\end{gathered}
$$

The results are normalized to get:

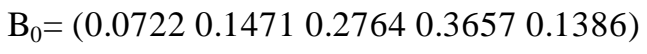

\section{F. Evaluation of membership}

After normalizing the fuzzy matrix R, we can get:

$\mathrm{R}_{0}=$

$$
\left(\begin{array}{ccccc}
0.1243 & 0.1845 & 0.1984 & 0.3821 & 0.1108 \\
0.1375 & 0.1000 & 0.3375 & 0.2750 & 0.1500 \\
0.0183 & 0.0747 & 0.2618 & 0.4556 & 0.1896 \\
0.0857 & 0.3714 & 0.3714 & 0.1714 & 0.0000 \\
0.0000 & 0.0435 & 0.2482 & 0.4824 & 0.2259
\end{array}\right)
$$

Based on the above analysis, China's current level of lowcarbon development of the shipping industry is still relatively low. Carbon levels in the industry, energy, technology, transport and the environment is not too high. The reason mainly is that China's development of low-carbon shipping was relatively late and investment in all aspects is not enough. Meanwhile, the technical level is relatively low, resulting in lower levels of low-carbon development of China's shipping industry.

Therefore, China should develop low-carbon shipping from industry, energy, technology, transport and environment aspects. Make appropriate plans, and then gradually increase the level of low-carbon development of shipping industry.

\section{Strategies of Low-Carbon DeVelopment of Shipping INDUSTRY}

From above analysis, industry factor, energy factor, technical factor, transport factor and environment factors have an important influence on the development of China's shipping industry. Therefore, in the development of low-carbon shipping, China should take appropriate measures.

\section{A. Optimize the industrial structure, develop the circular economy vigorously}

At present, $\mathrm{CO}_{2}$ emission from the shipping industry in our country is relatively large and the energy consumption is also very large. This is not in line with the economy concept 
of "green" economy and circular economy. Therefore, in order to develop low-carbon shipping, we must first adjust and optimize the industrial structure of China's shipping industry, integrate our shipping company through mergers or bankruptcy to eliminate some backward shipping companies. Secondly, optimize the industrial chain of shipping industry so that achieve "low-carbon" of upper, middle and downstream industries, shorten or cancel chain links of high energy consumption. Finally, vigorously promote the development of "green shipping industry", recycle maritime resources, adhere to the principle of "re-use", optimize the allocation of maritime resources and reduce waste. Government should increase the intensity of maritime projects, strictly limit and punish maritime projects of high energy consumption and high emission.

\section{B. Adjust structure of energy consumption, increase the use of clean energy and renewable energy}

The primary energy used by shipping industry is petroleum, the burning of petroleum leads to large emissions of $\mathrm{CO}_{2}$, and energy consumption structure of the shipping industry is very unreasonable. Our shipping company may try to use new energy, such as promoting the use of wind, solar, natural gas and other clean energy to replace oil and coal. At the same time, increase technology investment to find alternative and renewable energy, recycle energy and establish recycling system to improve energy efficiency.

\section{Increase the development of low-carbon technologies and persist in innovation}

Our current technology level of low-carbon shipping is still lagging behind, and the gap between the developed countries and China is still relatively large. China should support science and technology research by increasing financial funds ,establish special funds for the development of lowcarbon shipping, improve the access threshold of shipping industry and standardize China's maritime shipping company by low-carbon technology. To enhance the core competitiveness of the shipping industry, we should increase innovation of energy technology, develop personnel of low-carbon shipping and develop high-tech maritime facilities. Meanwhile, strengthen international exchanges and cooperation, learn and introduce advanced low-carbon technologies from developed countries. Domestic enterprises should also conduct independent innovation to possess key technologies developed independently by China.

\section{Improve the transport ship, eliminate outdated ship}

The main transport machine of shipping companies is transport ship. Thus, when it comes to transport, we should optimize ship structure of our shipping company, eliminate backward old ship, and increase the use of new vessels. Advanced energy-saving equipment and pollution treatment equipment should be installed to every transport ship. Sailing route and distance of the ship also should be optimized so that we can reduce emissions of $\mathrm{CO}_{2}$ by saving more time. Besides, a filter device should be installed to the place where ship exhausts tail gas, the pollution of the water in the process of sail- ing should be avoid. Finally, we should also pay attention to the deep treatment of other pollutants.

\section{E. Increase investment in environmental governance, establish environmental consciousness}

The development of low-carbon shipping source should focus on the head of source and end of source. On the one hand, we should reduce or even eliminate the presence of pollution at source, and avoid the phenomenon of pollution first and treatment it later. On the other hand, we should focus on contamination treatment after pollution. To develop lowcarbon shipping, it is necessary to increase efforts of pollution control, especially to focus on governance issues of marine pollution. At the same time, citizens have to establish the concept of maritime environmental protection, strengthen the supervision of shipping companies, report illegal shipping companies and offer suggestions for low-carbon development of the shipping industry.

\section{CONCLUSIONS}

From what has been discussed above, we may draw a sound conclusion that the development of China's low-carbon shipping industry is a long-lasting battle, every aspect and each factor should be rational planned. Development of lowcarbon shipping is a necessary requirement and an important part of the development of low-carbon economy, it will help to optimize the structure of China's shipping industry, improve the efficiency of the energy and efficiency of maritime resources. Therefore, we need to find measures to reduce $\mathrm{CO}_{2}$ emissions from all related aspects of shipping industry, the core is technology innovation. We need to develop China's shipping industry into low-power and high-efficiency "green shipping."

\section{REFERENCES}

[1] Li Jing. Impact of carbon tax on China's shipping industry based on CGE model. China Water Transport (lower half Month), 2011(12)

[2] Zhang Shuang, Zhang Shuo Hui, Li Yi Liang. Greenhouse gas reduction measures of international shipping. China Marine, 2008, 17(5)

[3] Wang JiaRui. Hierarchical fuzzy evaluation index system to build a lowcarbon economy and empirical research. Industrial Technology \& Economy,2014

[4] Liu Xiao Mei. Construction of evaluation system based on a low-carbon economy Fuzzy Analytic. China Securities Futures, 2013(1)

[5] Wang Hong, Liu Na, Song YaJing. Fuzzy comprehensive evaluation model for urban low-carbon economic evaluation. Learned journal of Hebei United University, 2013(2)

[6] Bi Peng, Zhang LiTing. Overall Evaluation of low-carbon economy based on Fuzzy Analytic Hierarchy Process-A Case Study of Heilongjiang. Learned journal of Harbin University of Commerce,2013(3)

[7] .Erik Haites. Linking emissions trading schemes for international aviation and shipping emissions. Climatepolicy, 2009(4)

[8] Williams, E. Light absorbing carbon emissions from commercial shipping, Geophysical Research Letters, 2008.

[9] Windson B.Shipping Company adopts carbon indexing The Motor Ship, 2008

[10] Thomas. A Grigalun as Shipping: on course for a green and clean future, MO News, 2007 